\title{
Орален полибактериален имуномодулатор фариностим - локален лигавичен имунитет при пациенти с УНГ-заболявания
}

\author{
М. Милков ${ }^{1}$, Ив. Ценев², Р. Шекерджийски³, Б. Петрунов ${ }^{3}$, Цв. Тончев ${ }^{1}$ \\ ${ }^{1}$ Медицински университет - Варна, Факултет по дентална медицина \\ 2МБАЛ "Царица Йоанна" - София \\ ЗЛЛаборатория имуномодулатори и антиоксиданти при ВМА - София
}

\begin{abstract}
Poly-bacterial immune stimulator for prophylaxis and treatment of inflammatory diseases of upper respiratory tract.

The global problem related to the drug poly-resistance of a significant number of microbial species forced the search for a new approach to the prophylaxis and control of the infectious diseases, such as mucosal vaccines and immune modulators. The oral poly-bacterial immune modulator Pharinostim made of killed cells and lisats of 6 microbial species (Haemophilus influenzae, Streptococcus pyogenes, Staphylococcus aureus, Neisseria catarrhalis, Klebsiella pneumoniae, Candida albicans), finds broader implication in the clinical practice for immune prophylaxis and treatment of ENT infections.
\end{abstract}

\section{Резюме}

Полибактериален имуностимулатор за профилактика и лечение на възпалителни заболявания на горните дихателни пътища

Глобалният проблем, свързан с лекарствената полирезистентност на значителен брой микробни видове, наложи търсенето на нови подходи за профилактика и контрол на причинените от тях заболявания, каквито са лигавичните ваксини и имуномодулаторите. Оралният полибактериален имуномодулатор фариностим (Ф), съставен от убити клетки и лизати на 6 микробни вида (Haemophilus influenzae, Streptococcus pyogenes, Staphylococcus aureus, Neisseria catarrhalis, Klebsiella pneumoniae, Candida albicans), намира все по-широко приложение в клиничната практика за имунопрофилактика и терапия на УНГ инфекции. $\prod$ риложението на орални полибактериални препарати е сравнително ново направление в имунопрофилактиката и имунотерапията на неспецифичните инфекциозни заболявания. Честото и безконтролно приложение на антибиотици и химиотерапевтици, водещо до селекция на резистентни бактериални щамове, наложи тьрсенето на нови подходи за профилактика и контрол, каквито са ваксините и имуномодулаторите [1-4]. Този факт мотивира и създаването на Международна изследователска група за нова антимикробна стратегия - ISGNAS (International Study Group on New Antimicrobial Strategies), която работи главно по проблема „Модулиране на лигавичния имунитет чрез пробиотикови микроорганизми (Probiotic microorgsnisms) - живи микроорганизми, най-често бактерии, прилагани перорално [5, 6] (според дефиницията на FAO/WHO пробиотиците са: „Живи микроорганизми, които, приложени в адекватни количества, са полезни за здравето на гостоприемника").

Терминът имуномодулатори обединява вещества с различен произход и структура, способни да променят покоя, пролиферацията и ефекторните функции на имунните клетки и да манипулират имунния отговор в негативна или позитивна насока, т.е. имуностимулатори и имуносупресори. Имуномодулацията е процес на повлияване динамиката, вида и силата на конкретния имунен отговор в резултат на действието на тези вещества и може да окаже няколко ефекта върху вродената и адаптивната имунна система: усилващ при нормална защитната функция, възстановяващ - при намалена функция и нормализиращ - при променена такава. През последните две декади се провеждат усилено 
експериментални и клинични проучвания върху биологично активни субстанции с различна химическа характеристика и механизъм на действие с цел приложението им като имуномодулатори: естествени (бактерии, фунги, растения), синтетични (пептиди и химични субстанции), биологични (рекомбинантни цитокини, растежни фактори) и др. Имуномодулаторите се определят още като: антиген-неспецифични - повишават функцията на имунната система (ИС), независимо от антиген и антиген-специфични - повишават функцията на ИС, ако са въведени заедно с конкретен антиген. Полибактериалните имуномодулатори се изявяват преди всичко като имуностимулатори. Много субстанции с микробен произход са прилагани за лечение на някои видове рак (на пикочния мехур, стомаха и др.), както и на някои рекурентни инфекции. През 80-те години на миналия век са създадени някои орални полибактериални препарати, съдържащи лиофилизирани бактериални лизати, като Broncho-Vaxom и Uro-Vaxom (OM Laboratories), чиито имунологични и клинични ефекти са наблюдавани в множество проучвания [4, 7-9]. Други известни полибактериални препарати за орално приложение са Ribomunyl, Imocur enfant, Immudon, описани от Божков и сътр., 1995 [10].

Научна група от НЦЗПБ в продължение на две десетилетия работи за създаването и характеризирането на български орални полибактериални имуномодулатори, съставени от специално подбрани бактериални видове, изолирани от пациенти със съответни заболявания. С цел да стимулират както неспецифичната имунна защита, така и специфичния имунен отговор, тези препарати имат уникална композиция едновременно от цели микробни клетки и бактериални лизати, която ги отличава от всички известни досега имуномодулатори. Включените в състава им Грам (+) (S. pyogenes, S. aureus) и Грам (-) (H. influenzae, N. catarrhalis, K. pneumoniae) микроорганизми и лизати съдържат различни адювантни компоненти с имуномодулаторна активност: ЛПЗ, липопротеини, ДНК, повърхностни мембранни протеини, тейхоева, липотейхоева киселина, муреин и др., които активират различни елементи на вродената и придобитата имунна защита - фагоцитоза, продукция на цитокини и антитела, пролиферация и активация на лимфоцити и др. [9, 11, 12]. Досега в медицинската практика намират широко приложение три орални полибактериални препаpaтa: Respivax (R) (Петрунов и сътр., 1991) - за заболявания на дихателните пътища; Urostim (U) (Митов и сътр., 1991) - за заболявания на пикочно-половата система и Dentavax (D) (Петрунов и сътр., 1993) - за заболявания на устната лигавица и пародонта. Тяхната имунологична и клинична ефективност е обект на редица експериментални и клинико-лабораторни проучвания, които дават убедителни доказателства за имуногенността им, за протективната им активност и за имунотерапевтичния им ефект [13-19]. Тъй като препаратите се прилагат перорално и следователно контактуват с най-мощните лигавични индуктивни места - асоциираната с носа лигавична имунна система и Пайеровите плаки в червата - от съществено значение е изследването на ефекта им върху лигавичния имунен отговор.

Фариностим, който е структурен аналог на другите български орални полибактериални препарати и е предназначен за имунопрофилактика и терапия на възпалителни заболявания на горните дихателни пътища (оро- и ринофаринкса). Съставът му е съобразен с най-честите причинители на тези инфекции. Целта на проучването е да се проследи ефективността му върху локалния лигавичен имунен отговор при пациенти с различни УНГ инфекции.

\section{Материали и методи}

\section{Обект на проучването}

Пациенти и имунизационна схема. В проучването, след подписано информирано съгласие, бяха включени 40 пациенти $(8-70$ г.) - 28 жени и 12 мъже, с остри, хронични и рецидивиращи УНГ заболявания (ринити, фарингити, синуити, тонзилити, отити). Подборът и контролът на клиничното състояние на пациентите се осъществи в І-ва УНГ клиника, УМБАЛ „Царица Йоанна“, София (д-р Н. Сапунджиев, проф. д-р И. Ценев). Препаратът фариностим се приложи перорално, по 4 таблетки за смучене дневно, разпределени равномерно за деня (през 3-4 ч.), в 20 последователни дни. Предварително пациентите бяха уведомени да не приемат течности и храна един час след приема на таблетката, за да се избегне разреждането и ускореното елиминиране на препарата през стомашночревния тракт.

Полибактериалният имуномодулатор фариностим (Pharynostim) („Натстим“ ЕООД) е съставен от лиофилизирани убити цели клетки и лизати от Haemophilus influenzae, Streptococcus pуogenes, Staphylococcus aureus, Neisseria catarrhalis, Klebsiella pneumoniae, Candida albicans. 1 таблетка за смучене съдържа 45 мг активна субстанция.

\section{Биологични материали}

Слюнка. Пробите бяха събирани на 0 (преди), 30-я и 60-я ден от началото на приложението на фариностим. Изследвана е цяла нестимулирана слюнка, взета сутрин на гладно или минимум 1 
час след прием на храна и течности, в стерилни епруветки, в количество 3-4 мл. След съответната обработка (центрофугиране на $4^{\circ} \mathrm{C}$ при $9000 \mathrm{~g}$ и добавяне на протеазен инхибитор) супернатантите се инактивираха при $56^{\circ} \mathrm{C}$ за $30 \mathrm{~min}$ и се съхраняваха при $-20^{\circ} \mathrm{C}$. Материалите от един пациент бяха изследвани едномоментно, в двойни проби.

\section{Методи}

Определяне на количеството на IgA и IgG се извърши с имунодифузионен метод (РИД) за определяне на ниски концентрации имуноглобулини в слюнка („Имунотест“, България) [20].

Определяне на специфични антитела в слюнка. Специфичните антимикробни антитела бяха определени c home made ELISA c антиген убити бактериални клетки от съответните 6 вида, включени в препарата $\Phi$, използвайки вече описан метод за ЛПЗ антигени [21] със слюнки, разредени 1:10. След съответните инкубации с пероксидазни античовешки IgA, IgM и IgG конюгати (БулБио-НЦЗПБ ЕООД) и субстрат-хромогенния разтвор, оптичната плътност (OD) на пробите беше измерена на Multiscan MCC/340 (Labsystems) при дължина на вълната $492 \mathrm{~nm}$.

Статистически анализ. Резултатите бяха анализирани със софтуерна приложна програма SPSS 13.0. Стойност на $\mathrm{p}<0.05$ е приета за достоверна.

\section{Резултати и обсъждане}

Изследването на лигавичния имунитет е винаги предизвикателство поради трудностите, свързани с измерването на секреторни антитела във външ- ните секрети, както и с изолирането на лимфоидни клетки от различните лигавично-асоциирани тъкани. Лигавичните повърхности са отворена система и значителна част от локално продуцираните антитела се губи със секретите. Секреторният S-IgA е най-добрият ефекторен механизъм, който заедно с вродените защитни бариери осъществява протекцията на лигавичните повърхности, т.нар. първа линия на защита [22, 23].

Слюнката е най-предпочитаният източник на секреторни имуноглобулини в клиничната имунология, а слюнчените S-IgA се предлагат от някои автори като индекс на лигавичния имунитет [2426]. Ниските нива на секреторен $\operatorname{IgA}$ в слюнката се разглеждат като рисков фактор за инфекции на горните дихателни пътища при деца и възрастни и често се асоциират с наличието на зъбен кариес и периодонтални заболявания [24, 25]. Индивидуални различия в количеството на слюнчения IgA могат да повлияят защитата на организма при някои инфекции. Натрупват се все повече данни и за приноса на локално синтезираните и трансудираните IgG антитела в защитата на лигавиците. Пасивният парацелуларен и рецепторномедиираният транспорт на IgG имат решаваща защитна функция на повърхности с ограничено протеолитично разграждане, каквито са респираторният и женският генитален тракт [27].

Резултатите от настоящото проучване на количеството на имуноглобулините в слюнката показаха значимо повишение на секреторния $\operatorname{IgA}(\mathrm{S}-\operatorname{IgA})$ при $52 \%$ от третираните пациенти след приема на имуномодулатора фариностим (р $<0.0001$ на 30 ден и $\mathrm{p}=0.004$ на 60 ден) (Фиг. 1).

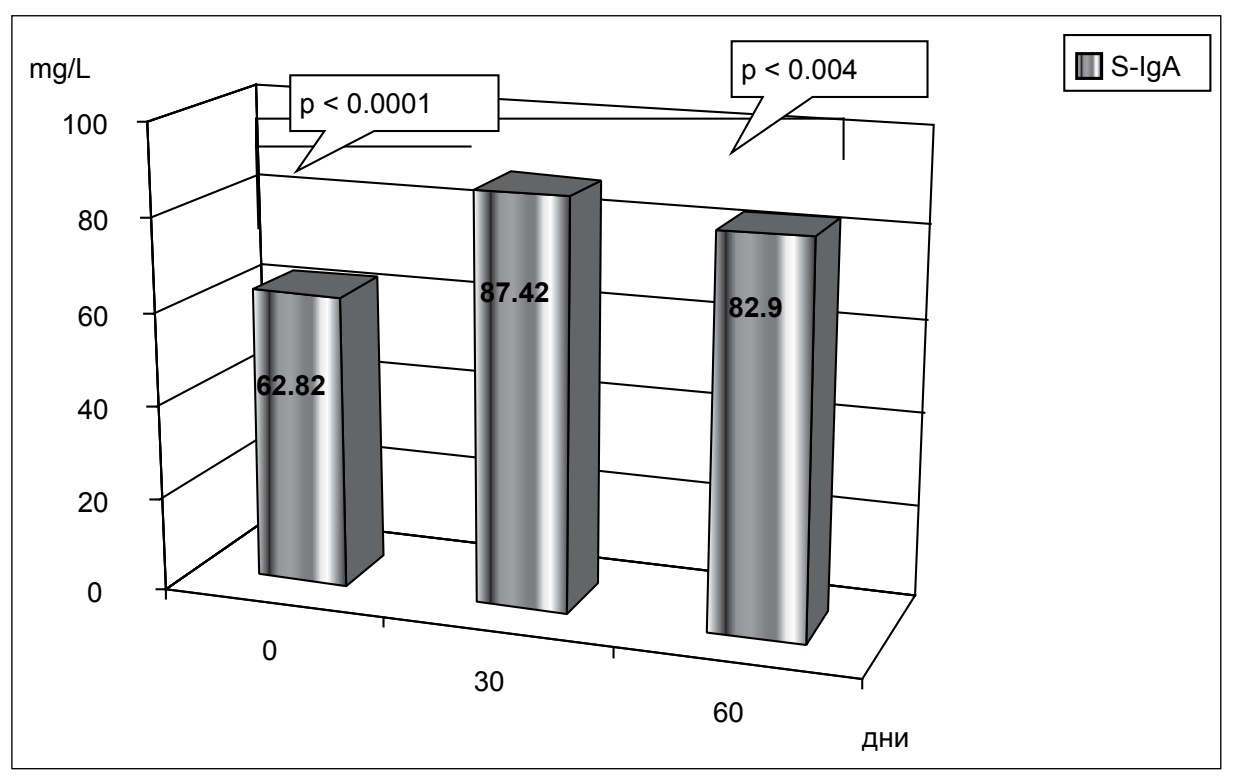

Фиг. 1. Повишени нива на слюнчените S-IgA имуноглобулини след приложението на Ф при пациенти 
Същевременно беше установено достоверно понижение на количеството на слюнчените IgG на 30 ден от началото на терапията в сравнение с изходното му ниво $(\mathrm{p}<0.0001)$ при повече от $1 / 2$ от проследяваните пациенти (Фиг. 2).

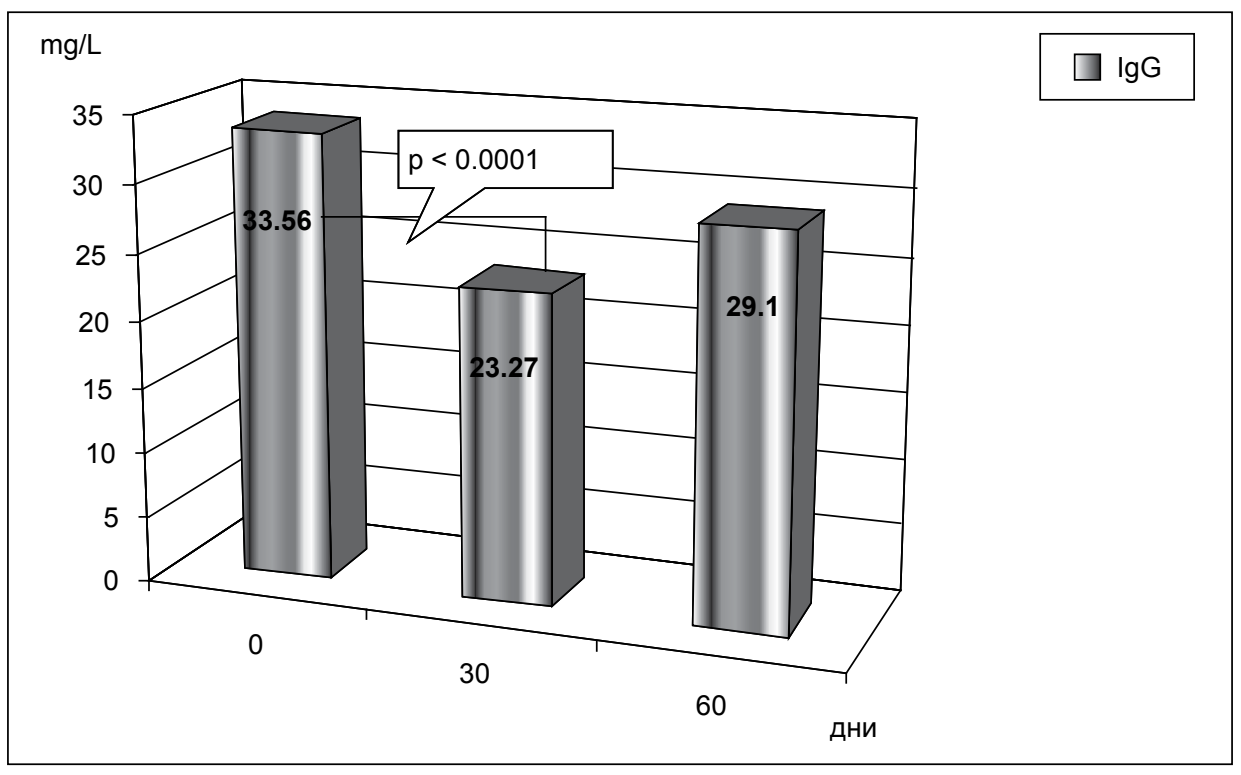

Фиг. 2. Понижение на количеството на $\operatorname{lgG}$ в слюнката след приложението на Ф при пациенти

Добре известно е, че секреторните IgA са преобладаващият клас имуноглобулини във външните секрети и са основен протектор на лигавиците, в частност на лигавицата на устната кухина и горните дихателни пътища. Те осигуряват специфична имунна защита, блокирайки свързването и проникването на различни патогени - бактерии, вируси, паразити, токсини, алергени [22]. В тази връзка намереното повишение на количеството на S-IgA в слюнката след приложението на Ф говори за позитивния ефект на препарата върху неспецифичния локален имунитет при пациентите с УНГ заболявания. Това наблюдение се потвърждава и от понижението на количеството на слюнчения $\mathrm{IgG}$, който е предимно с трансудатен произход и значително се увеличава при наличие на локално дразнене и възпаление в лигавиците.

При всички предварителни изследвания (ден 0) на слюнката бяха регистрирани антибактериални антитела от трите имуноглобулинови класове, които се дължат на постоянното антигенно дразнене от присъстващите в устната кухина стотици бактериални видове. Данните за специфичните към компонентите на $\Phi$ антитела в слюнката показаха два типа реакции. Тип I беше наблюдаван при пациенти с ниски нива преди терапията. При тях специфичните IgG, IgM и IgA антитела се повишиха на 30 ден. При тип II реакция изходните нива на антителата бяха по-високи, понижиха се на 30. ден и се покачиха в края на наблюдавания период. Интересно е да се отбележи, че определено доминираше тип I отговорьт - значително повишение на слюнчените антитела на 30 . ден се установи при 53 до 82 процента (в зависимост от изследвания бактериален вид) от проследяваните пациенти (табл. 1). Вторият тип реакция с понижение на антителата и последващо повишение се регистрира при значително по-мальк процент от изследваните (от 18 до 47\%).

Таблица 1. Пациенти (\%) с тип I отговор на специфичните слюнчени антитела след приложението на Ф:

\begin{tabular}{|c|c|c|c|c|c|c|}
\hline $\begin{array}{c}\text { Слюнчени } \\
\text { антитела }\end{array}$ & S. aureus & S. pyogenes & C. albicans & H. influenzae & K. pneumoniae & B. catarrhalis \\
\hline $\lg A$ & 60.5 & 52.6 & 71.1 & 65.8 & 55.3 & 63.2 \\
\hline $\lg$ & 71.1 & 55.3 & 63.2 & 60.5 & 52.6 & 68.4 \\
\hline $\operatorname{lgG}$ & 68.4 & 60.5 & 58 & 71.1 & 68.4 & 81.6 \\
\hline
\end{tabular}


Динамиката на преобладаващия I тип отговор на антибактериалния лигавичен имунитет е представена на Фигури 3-5. Те показват развитието на добър лигавичен имунен отговор, демонстриран чрез статистически достоверно (р от $<0.0001$ до $0.04)$ повишение на трите класове имуноглобулини (A, M, G) към всички микробни видове в препарата $\Phi$ на 30 . ден от началото на терапията в сравнение с изходните им стойности (ден
0) (Wilcoxon test). Характерно беше също така, че наблюдаваното повишение на специфичните слюнчени антитела в повечето случаи се последва от понижение на 60 . ден от началото на терапията. Изключение правеха само антителата срещу C. albicans $(p=0.014$ за IgA; $p=0.042$ за IgG; $p=$ 0.022 за IgM) и IgA антителата към H. influenzae (p $=0.03$ ), които останаха значително повишени до края на наблюдението (60. ден).

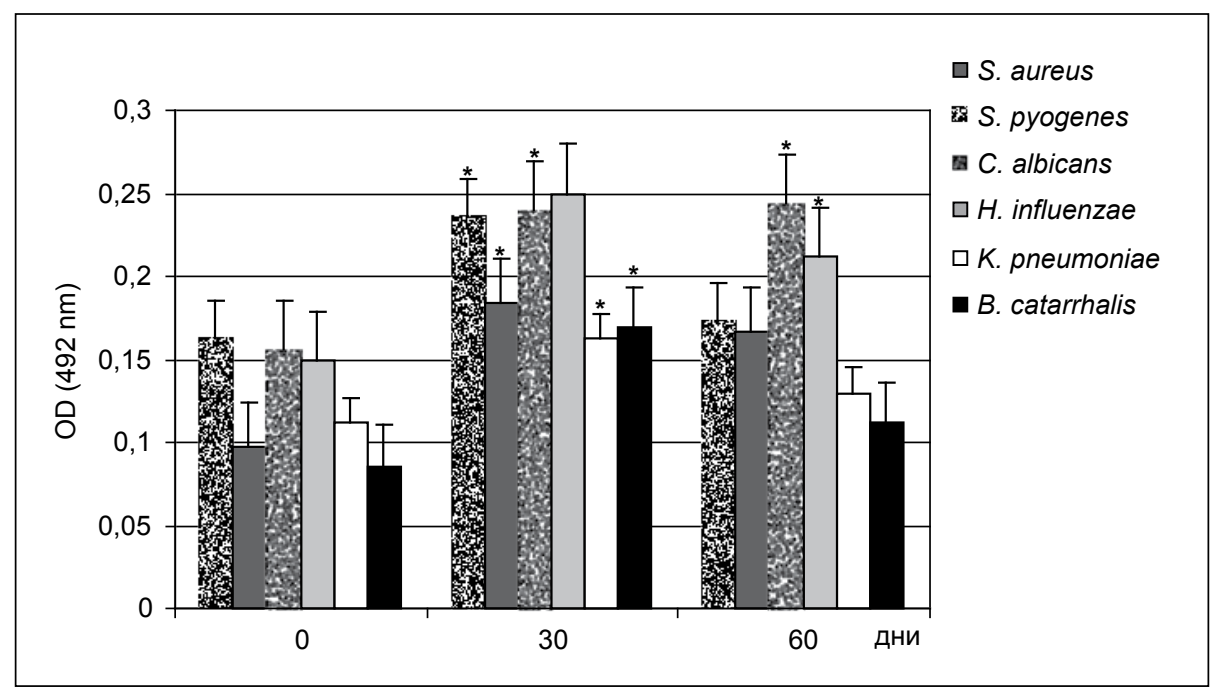

*стойности на р от < 0.0001 до 0.03

Фиг. 3. Повишени нива на специфичните антибактериални слюнчени $\lg \mathrm{A}$ антитела след приложението на фариностим

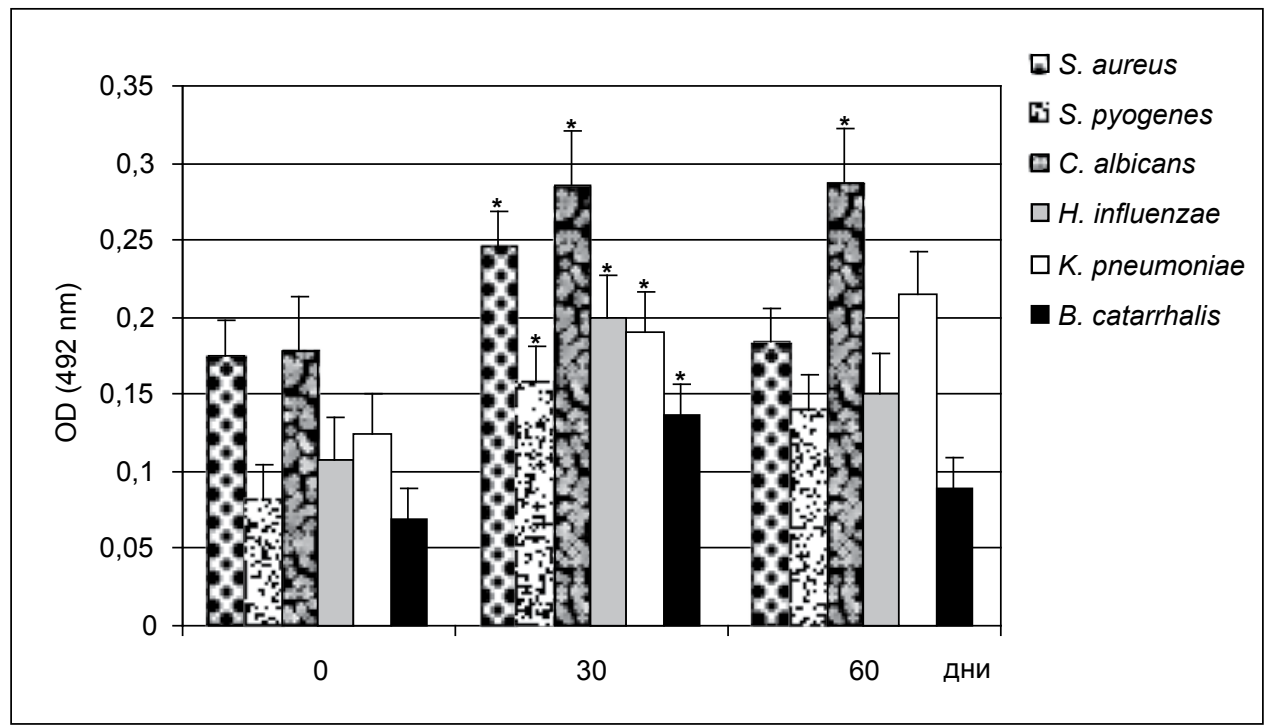

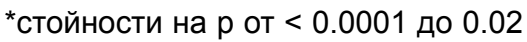

Фиг. 4. Повишени нива на специфичните антибактериални слюнчени IgM антитела след приложението на фариностим 


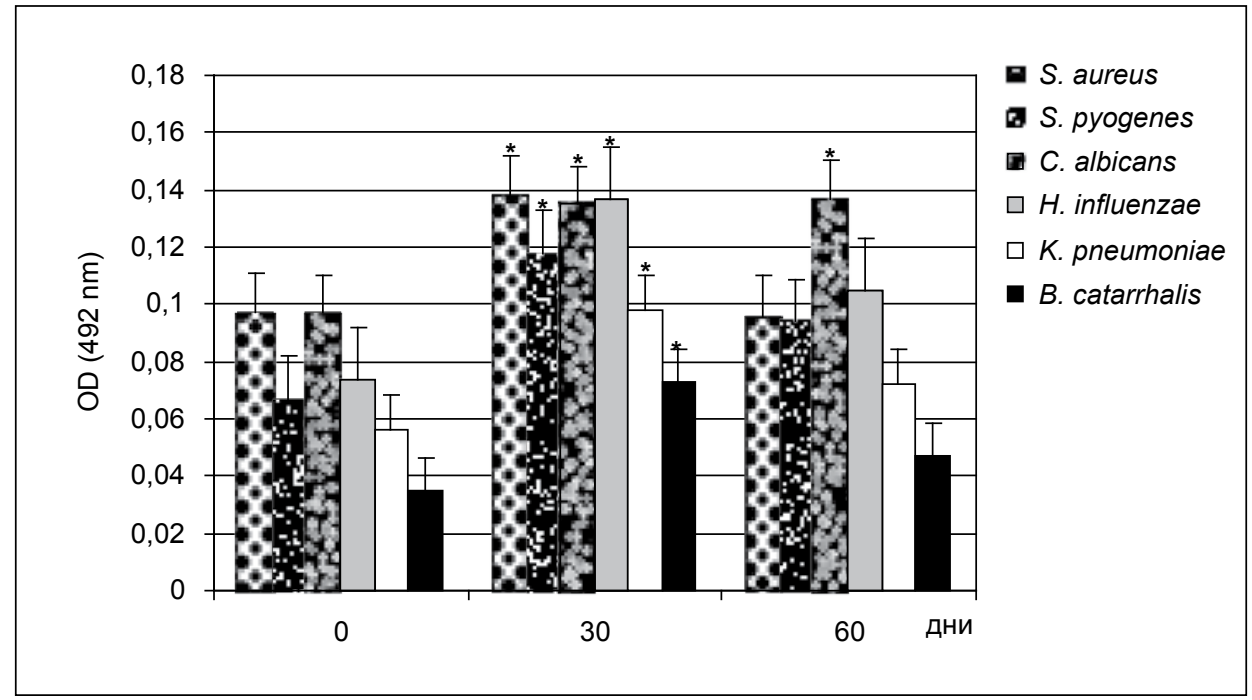

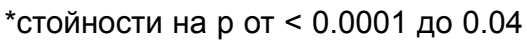

Фиг. 5. Повишени нива на специфичните антибактериални слюнчени IgG антитела след приложението на фариностим

Регистрираните два типа хуморален имунен отговор са съществено доказателство за имуномодулиращия ефект на препарата фариностим. Същите два типа реакции сме установили в предишни наши проучвания с други два български орални полибактериални имуномодулатора - уростим и дентавакс, приложени на пациенти със съответни заболявания. И при трите препарата - уростим, дентавакс и фариностим - се установяват някои характерни закономерности в динамиката на имунния отговор: при голям процент от изслед- ваните пациенти се наблюдава стимулиране на синтезата на специфичните срещу компонентите на имуномодулаторите антитела, както лигавични, така и серумни, и се повишава количеството на слюнчения секреторен IgA и на серумните имуноглобулини [28-32]. Наблюдаваните два типа позволяват да се оформи един модел на имуномодулиращия ефект на българските орални полибактериални имуномодулатори върху специфичния лигавичен и системен хуморален имунен отговор, представен на фиг. 6.

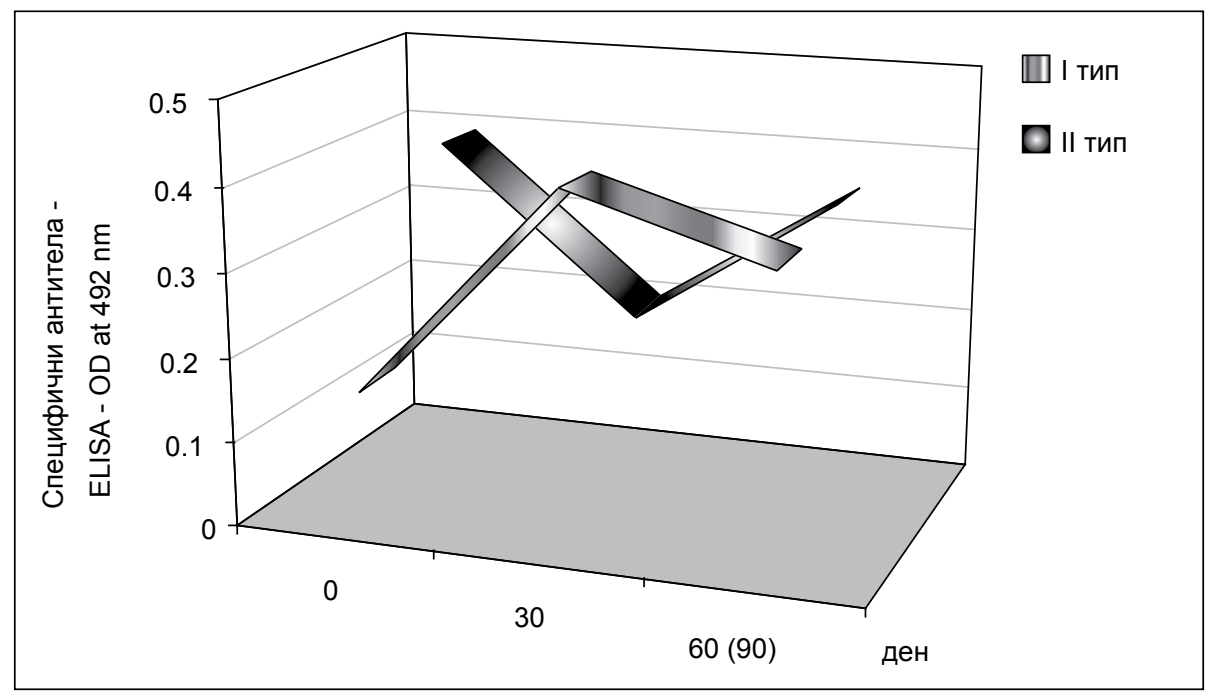

*тип I - при пациенти с ниски стойности на антибактериалните антитела преди терапията се регистрира повишение на антителата;

*тип II - при пациенти с високи базови стойности се установява понижение, последвано от повишение

Фиг. 6. Модел на имуномодулиращия ефект на българските орални полибактериални имуномодулатори върху специфичния лигавичен и системен хуморален имунен отговор 
Различните схеми на приложение на трите имуномодулатора предизвикват някои различия в динамиката на синтеза на специфичните антитела при I тип реакция на хуморалния имунен отговор. При пациентите, третирани с уростим (х 1 табл./дневно, 90 дни), постоянното присъствие на антиген стимулира синтезата на антитела до края на наблюдавания период (90. ден). При дентавакс и фариностим, които имат една и съща схема на приложение при пациентите (х 4 табл. за смучене/ дневно, 20 дни), имунният отговор протича „класически“ - с пик (на 30. ден) и спад (на 60. ден). Приликите между двата препарата се установяват и при изследването на неспецифичния лигавичен имунитет. От една страна се открива значително

\section{Литература:}

1. Bessler WG, P Beck, U Konetznick, M Loleit, E Sedelmeier, P Hoffman, M Strecker, S Stöclin (1991). Biological Activity of Bacterial Surface Components. Immunogenicity and Immunomodulatory properties of a bacterial extract from Escherichia coli. Arzneimittel-Forschung Drug Research, 41(I) (3): 274.

2. Rosenthal M. (1986) Effect of a bacterial extract on cellular and humoral immune responses in humans. J. Immunopharmac., 8:315322.

3. McGhee JR and H Kiyono (1993). New perspectives in vaccine development: mucosal immunity to infections. Infect. Agents and Dis., 2: 55-73.

4. Koukalova D, V Hajek, R Kodusek (1999). Development of a vaccine for treatment of urinary tract infections. Bratisl. Lek Listy, 100 (2): 92.

5. Boersma WJA (1998). Modulation of mucosal immunity by probiotic microorganisms. Mucosal Immunology Update, 6(3): 5.

6. Karimi O and AS Pena (2003). Probiotics: Isolated bacterial strain or mixtures of different strains? Two different approaches in the use of probiotics as therapeutics. Drugs Today (Barc.), 39(8): 565.

7. Derenne JPh and B Declaux (1992). Clinical experience with OM$85 \mathrm{BV}$ in upper and lower respiratory tract infections. Respiration, 59(Suppl.3): 28-31.

8. Emmerich B, K Pachmann, D Milatovic, HP Emslander (1992). Influence of OM-85 BV on different humoral and cellular immune defense mechanisms of the respiratory tract. Respiration, 59 (Suppl.3): 19-23.

9. Huber M, K Krauter, G Winkelmann, HW Bauer, VW Rahlfs, PA Lauener, GSS Bleßmann, WG Bessler (2000). Immunostimulation by bacterial components: II. Efficacy studies and meta-analysis of the bacterial extract OM-89. Int. J. Immunopharmac., 22 (12): 1103.

10. БожковБ (1998). Имунотерапия. Под ред. на Б. Божков, МИ „Арсо“, София.

11. Jonson AG (1994). Molecular adjuvants and immunomodulators. New approaches to immunization. Clin. Microbiol. Rev., 7(3): 277-289.

12. Hoffmann $\mathrm{P}, \mathrm{K}$ Mittenbuhler, WG Bessler, L Heinevetter, KH Wiesmuller, G Jung, W Baier, M Huber, AR Lorenz, UVD Esche (1997). Bacterial cell wall components as immunomodulators - I. Lipopeptides as adjuvants for parenteral and oral immunization. Int. J. Immunopharmac., 19(9-10):547.

13. Markova R, S Marinova, B Petrunov, J Cvetanov, P Nenkov, A Radinov, L Tchorbadjiiska, D Konstantinova (1997). Stimulating Effect of an Oral Polybacterial Immunomodulator on the Proliferative Activity of Guinea Pig Lymphocytes. Int. J. Immunopharmac., 19(4): 205.

14. Nenkov P, I Mitov, S Marinova, R Markova (1995). Experimental Investigations on the Immunomodulating Activity of Polybacterial повишение на количеството на секреторния $\operatorname{IgA}$ в слюнката при голям брой от пациентите, приемащи както фариностим, така и дентавакс, което доказва стимулиращия ефект на двата препарата по отношение на локалния имунитет в лигавиците на устната кухина и горните дихателни пътища. От друга страна положителният им ефект се потвърждава от понижението на количеството на слюнчения $\operatorname{IgG}$, за който е известно, че се увеличава при локално дразнене и възпаление.

В заключение данните от нашето проучване показват, че фариностим е убедителен имуностимулатор на хуморалния лигавичен имунен отговор, специфичен и неспецифичен, при пациенти със УНГ заболявания.

Preparation for Oral Immunotherapy and Immunoprophylaxis of Uroinfections. Int. J. Immunopharmac., 17(6): 489.

15. Petrunov BP (2004). Polybacterial immunostimulators in medical practice. Zh. Mikrobiol. Epidemiol. Immunobiol., (6): 122-6.

16. Petrunov B (2006). Polybacterial immunostimulants in the treatment and prophylaxis of respiratory infections and infectious/intrinsic brochial asthma. Int. J. Immunorehabilitation, 8(1): 19-21.

17. Йосифов Й, С Бакалова, М Коларова, С Станкова (1989). Приложение на Респивакс при лечението на някои остри белодробни инфекции при деца в двйно сляп опит. Педиатрия, 3: 110-112.

18. Кисьова К, Д Ковачев, Б Петрунов, П Ненков, Д Петкова, М. Пенева (1992). Оптимизиране на терапевтичните схеми на Респивакс посредством определяне на титъра на специфичните антитела към бактериалните му компоненти. Инфектология, XXIX (1): 30-33.

19. Nenkov P (2000). Overview on the Clinical Studies with Urostim Immunostimulator against Urogenital Infections. Genes and Proteins Underlying Microbial Urinary Tract Virulence. Ed. Emody et al., Kluwer Academic Plenum Publisher, 325-329.

20. Костадинова Р, И Стоянова, П Колева, С Маринова (2006). Количествени показатели на лигавичния имунитет за българската популация в норма и патология. Инфектология, XLIII (2): 26-30.

21. Marinova S, L Tchorbadjiiska, B Petrunov, J Cvetanov, P Nenkov, D Konstantinova, R Markova (2000). Immunostimulating and protective effects of an oral polybacterial immunomodulator „Dentavax“ in a rabbit experimental model. Int. J. Immunopharmac., 22: 843.

22. Brandtzaeg P (2003). Role of secretory antibodies in the defence against infections. Int. J. Med Microbiol., 293(1): 3-15.

23. Woof JM and J Mestecky (2005). Mucosal immunoglobulins. Immunol. Rev., 206: 64-82.

24. Jackson S, J Mestecky, Z Moldoveanu, P Spearman (1999). Collection and processing of human mucosal secretions. In Mucosal immunology, Ed. P. Ogra, Academic press, San Diego: 1567-1575.

25. Drummond PD and B Hewson-Bower (1997). Increased psychosocial stress and decreased mucosal immunity in children with recurrent upper respiratory tract infections. J. Psychosom. Res., 43: 271.

26. Jemmott JB III and DC McClelland (1989). Secretory IgA as a measure of resistance to infectious disease: Comments on Stone, Cox, Valdimarsdottir, and Neale. Behavioral Medicine, 15: 63-71.

27. Brandtzaeg P, ES Baekkevold, IN Farstad, FL Jahnsen, FE Johansen, EM Nilsen, T Yamanaka (1999). Regional specialization in the mucosal immune system; what happens in the microcompartments? Immunol. Today, 20(3): 141-151.

28. Marinova S, P Nenkov, R Markova, S Nikolaeva, R Kostadinova, I Mitov, M Vretenarska (2005). Cellular and humoral systemic 
and mucosal immune responses stimulated by an oral polybacterial immunomodulator in patients with chronic urinary tract infections. Int. J. Immunopathol. Pharmacol., 18(3): 457-473.

29. Ненков П, Р Маркова, И Митов, С Маринова, С Николаева, Р Костадинова, М Вретенарска, А Михова, Х Тасков (2005). Стимулиращ ефект на оралния полибактериален имуномодулатор „Уростим“ върху клетъчния имунен отговор у пациенти с хронични уроинфекции. Инфектология, XLII (4): 24-28.

30. Вретенарска М, П Ненков, С Маринова, Р Костадинова, Р Маркова, С Николаева, И Митов (2006). Клинични проучвания при пациенти с хронични уроинфекции, приемащи оралния полибактериален имуномодулатор „Уростим“. Урология, 12(1): 16-24.
31. Костадинова Р, С Маринова, П Ненков, Р Маркова, С Николаева, И Митов, М Вретенарска (2006). Стимулиращ ефект на оралния полибактериален имуномодулатор „Уростим“ върху хуморалния системен и лигавичен имунитет у пациенти с хронични уроинфекции. Съвременна медицина, 2: 9-17.

32. Янкова P (2006). Проучване на лигавичния имунитет при здрави доброволци, пациенти с различни заболявания и в условия на имуномодулация и индустриални замърсявания. Дисертационен труд за присъждане на образователна и научна степен „Доктор“. 